\title{
Synthesis and Growth Stimulant Properties of 2-Acetyl-3,7-dimethyl-5H-thiazolo[3,2-a]pyrimidin-5-one Derivatives
}

\author{
Vergush A. Pivazyan, ${ }^{1}$ Emma A. Ghazaryan, ${ }^{2}$ Roza S. Shainova, ${ }^{1,2}$ Rafael A. Tamazyan, \\ Armen G. Ayvazyan, ${ }^{3}$ and Aleksandr P. Yengoyan ${ }^{1,2}$ \\ ${ }^{1}$ National Agrarian University of Armenia, 74 Teryan Str., 0009 Yerevan, Armenia \\ ${ }^{2}$ Armenian-Russian (Slavonic) State University, 123 H. Emin Str., 0051 Yerevan, Armenia \\ ${ }^{3}$ STC OPC Molecule Structure Research Center of NAS RA, 26 Azatutyan Av., 0014 Yerevan, Armenia
}

Correspondence should be addressed to Aleksandr P. Yengoyan; ayengoyan@mail.ru

Received 12 October 2016; Revised 5 December 2016; Accepted 12 December 2016; Published 18 January 2017

Academic Editor: Xinyong Liu

Copyright (C) 2017 Vergush A. Pivazyan et al. This is an open access article distributed under the Creative Commons Attribution License, which permits unrestricted use, distribution, and reproduction in any medium, provided the original work is properly cited.

\begin{abstract}
A convenient, accessible, and high yield method for preparing of 6-methyl-2-thioxo-2,3-dihydropyrimidin-4(1H)-one (1) by treatment of acetoacetic acid ethyl ester with thiourea in sodium methylate was developed. The alkylation of the latter with 3-chloropentane-2,4-dione and further regioselective cyclization of intermediate compound (2) in high yield afforded 2-acetyl-3,7-dimethyl$5 \mathrm{H}$-thiazolo[3,2-a]pyrimidin-5-one (3). The halogenation and some transformations of synthesized thiazolo[3,2-a]pyrimidine (3) due to its ketone group were carried out to obtain the corresponding carboxamide, carbothioamide, sulfonohydrazide, and oxime and its alkylated derivatives (5). At preliminary biological studies the synthesized compounds have shown growth stimulant properties. The activity of four of them was higher than 70\%, compared with heteroauxin.
\end{abstract}

\section{Introduction}

Thiazole and pyrimidine are classes of heterocycles that are of considerable interest because of the wide range of their biological properties. Among them there are many pharmaceutically important molecules and chemical means of plants protection. Thiazolopyrimidines, which consist of these two active pharmacophore heterocycles, can also be of interest as potential bioactive molecules and have acquired a growing importance in the field of medicinal chemistry. Due to the great potential of both of the moiety, different scientists synthesized a large number of thiazolopyrimidines derivatives in particular thiazolo[3,2-a]pyrimidines with different substituents to evaluate their various pharmacological activities. The survey of literature reveals that these fused biheterocyclic compounds show pharmacological properties like anti-inflammatory [1-3], bactericidal [4-9], analgesic and antiparkinsonian [10], antifungal $[6,7,9,11-14]$, antioxidant $[6,9,15]$, anticancer [16-20], antimicrobial [9, 21-26], hypoglycemic [27], psychopharmacological [28], antituberculosis
[29], antidepressant [30], and antiviral [31, 32]. Some derivatives are offered as acetylcholinesterase inhibitors [3], antipsychotic agents [33], calcium antagonists [34], phosphate inhibitors [35, 36], and 5-HT2A receptor antagonists [37].

However, to our surprise, there are virtually no data in the literature about pesticidal and plant growth regulatory properties of thiazolo[3,2-a]pyrimidines. Only a few studies of pesticidal [38, 39], herbicidal [40], and growth regulatory activities [41] of these systems derivatives may be noted.

Prompted by the potential importance of this condensed biheterocyclic system the present investigation was undertaken to synthesize a series of novel thiazolo[3,2a]pyrimidines derivatives to obtain the new chemical means of plants protection and growth regulators [42].

\section{Results and Discussion}

2.1. Chemistry. As precursors for the synthesis of thiazolo[3,2-a]pyrimidines the substituted pyrimidines and 


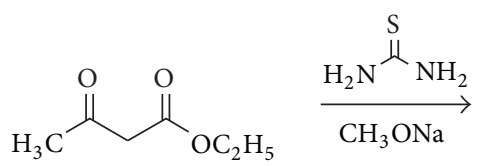<smiles>Cc1cc(O)nc(=S)[nH]1</smiles>

(1A)<smiles>Cc1cc(=O)[nH]c(=S)[nH]1</smiles>

(1B)<smiles>Cc1cc(O)[nH]c(=S)n1</smiles>

(1C)

SCHEME 1: Synthesis of 6-methyl-2-thioxo-2,3-dihydropyrimidin-4(1H)-one.

aminothiazoles are used. In most of the papers the synthesis of initial pyrimidine-2-thione derivatives is carried out via Biginelli multicomponent condensation reaction of substituted aldehydes with 1,3-dicarbonyl compounds and thiourea $[3,6,8,9,13,20,23]$. In some cases, pyrimidines were obtained in two steps [20]. In these syntheses the yield of pyrimidine derivatives was $50-85 \%$. Their further condensation with substituted acyl chlorides, halocarboxylic acids esters, or dicarbonyl compounds affords thiazolo[3,2a]pyrimidine biheterocyclic systems. In order to accelerate the synthesis of targeted thiazolo[3,2-a]pyrimidines and increase their yield, some authors used MW irradiation [9, $14,43]$ or catalysts $[44,45]$.

The cyclization of pyrimidine derivatives may yield several isomers, due to substitution position in pyrimidine cycle in the intermediate product. To achieve regioselectivity, the cyclization reaction was carried out with bromomalononitrile [9] or via S-propargyl derivatives [44, 45].

To obtain thiazolo[3,2-a]pyrimidines some authors use 2aminothiazoles as precursors. In these cases targeted compounds were obtained by cyclization of 2 -aminothiazole derivatives with bis(methylthio)methylene malononitrile [15], benzylidene malononitrile [9], 2-acetylbutyrolactone [37], and formamide and formic acid [41]. In [14, 43] 2-aminothiazole was used in Biginelli reaction instead of thiourea. A series of thiazolo[3,2-a]pyrimidinones were synthesized in a two-step procedure, using Eaton's reagent to effect the cyclization of 2-aminothiazoles [46].

In order to develop a convenient, accessible, and high yield method for preparing of 6-methyl-2-thioxo-2,3-dihydropyrimidin-4(1H)-one, in present investigation acetoacetic acid ethyl ester was treated with thiourea in sodium methylate (Scheme 1). Obtained compound can exist in different tautomeric forms $(\mathbf{1 A}-\mathbf{1 C})$. In ${ }^{13} \mathrm{C}$ NMR spectra the signal of double $\mathrm{C}=\mathrm{S}$ bond at $175.83 \mathrm{ppm}$ and in ${ }^{1} \mathrm{H}$ NMR spectra one broaden average absorption at $11.98 \mathrm{ppm}$ are observed. These data indicate that 6-methyl-2-thioxo-2,3-dihydropyrimidin$4(1 \mathrm{H})$-one has structure $(\mathbf{1 B})$.

To obtain targeted thiazolo[3,2-a]pyrimidine, compound 1 interacted with 3-chloro-pentane-2,4-dione (Scheme 2). At this process the substitution may occur at sulfur or one of cyclic nitrogen atoms, due to position of hydrogen atoms in pyrimidine moieties. In ${ }^{13} \mathrm{C}$ NMR spectrum of compound 2 the signal of $\mathrm{C}=\mathrm{S}$ carbon atom has disappeared and in ${ }^{1} \mathrm{H}$ NMR spectrum besides the signal of enol hydrogen atom (17.30 ppm, integral intensity equal to 0.9 ) also the second absorption for cyclic $\mathrm{OH}$ or $\mathrm{NH}$ group is observed $(12.20 \mathrm{ppm})$. These data indicated that the substitution

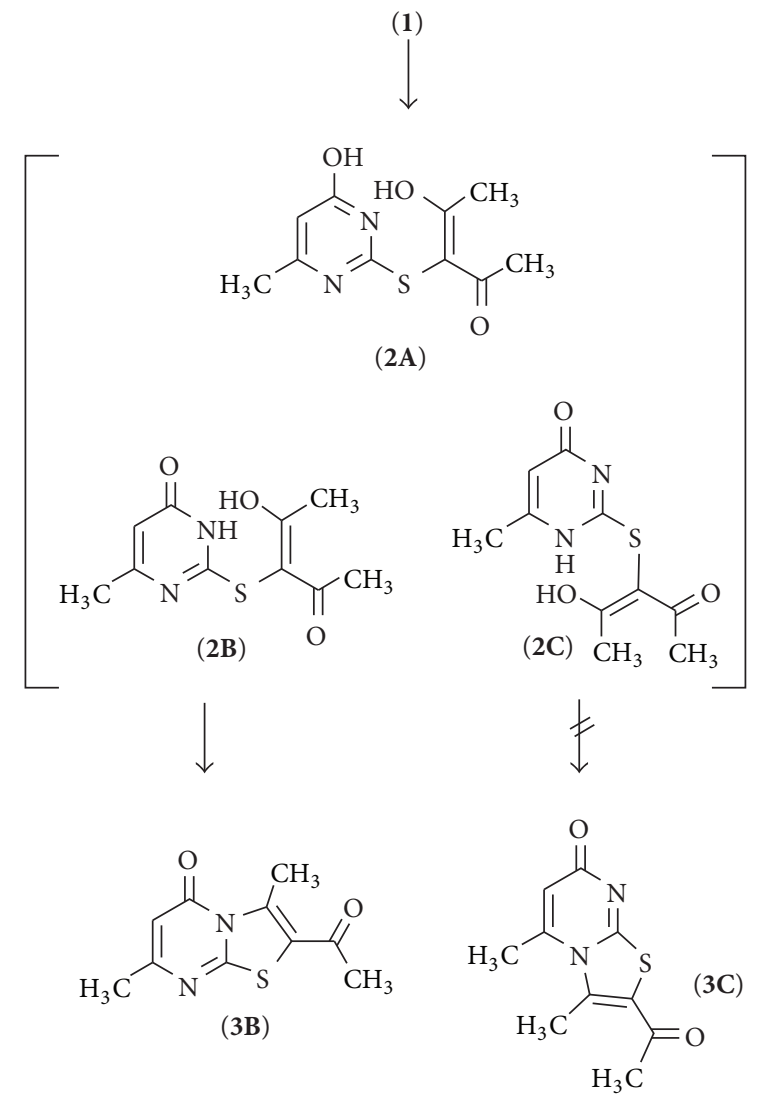

Scheme 2: Synthesis of 2-acetyl-3,7-dimethyl-5H-thiazolo[3,2a]pyrimidin-5-one.

occurred at sulfur atom and depending on tautomerism of heterocyclic ring and pentadione moiety the obtained compound may be described by one of the structures $(2 \mathrm{~A}$, 2B) or (2C). The heating of the latter in toluene at 125$130^{\circ} \mathrm{C}$ in the presence of toluene-4-sulfonic acid afforded compound (3). The intramolecular dehydration and cyclization can occur from tautomers (2B) or (2C) and as a result 2-acetyl-3,7-dimethyl-5H-thiazolo[3,2-a]pyrimidin-5one (3B) or 2-acetyl-3,5-dimethyl-thiazolo[3,2-a]pyrimidin7-one (3C) can be obtained.

Since the further transformations have been carried out on the basis of this compound (3), its structure was strictly proved by $\mathrm{X}$-ray diffraction analysis, whose data unambiguously agree with the structure (3B) (Figure 1).

To introduce some pharmacophore groups into molecule structure, some transformations due to the ketone 


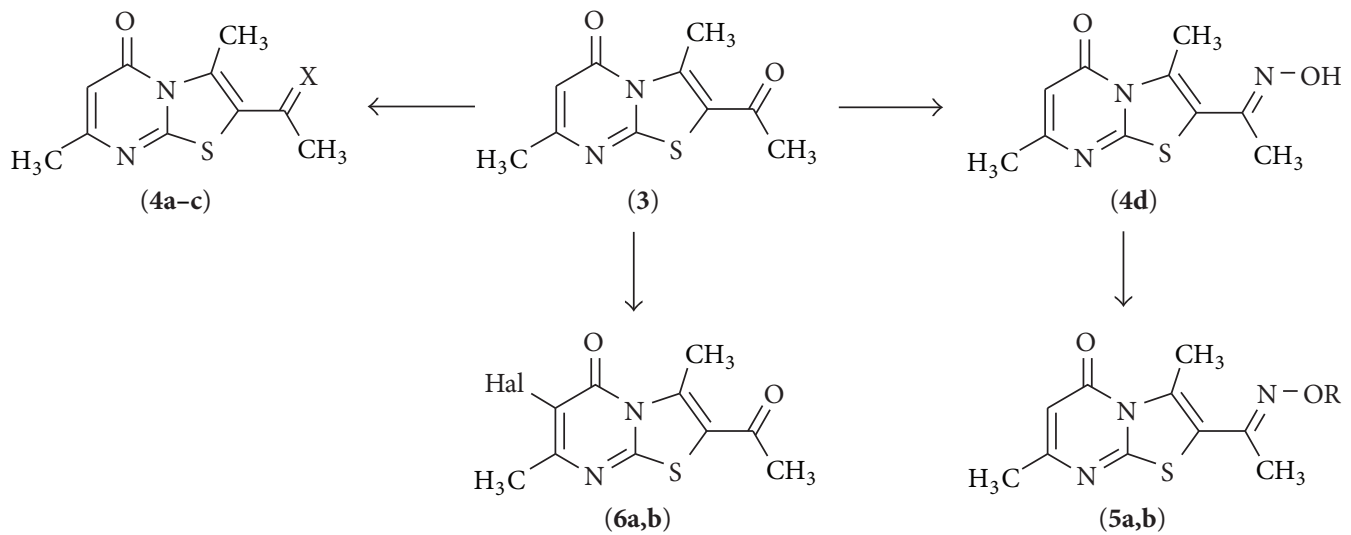

SCHEME 3: Transformations of 2-acetyl-3,7-dimethyl-5H-thiazolo[3,2-a]pyrimidin-5-one.

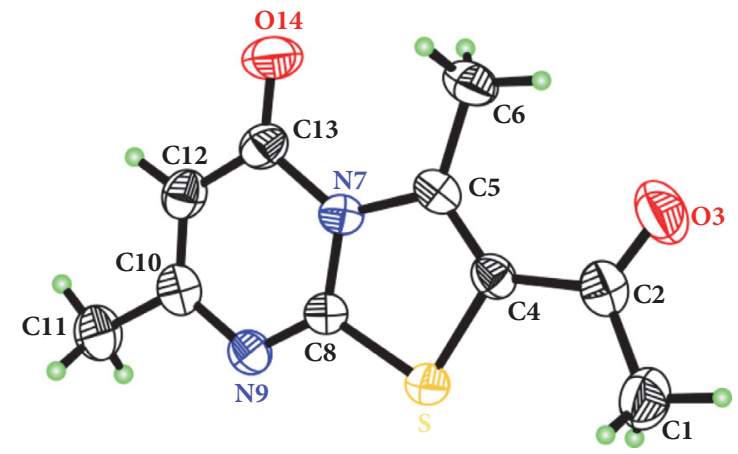

FIgURE 1: The structure of 2-acetyl-3,7-dimethyl-5H-thiazolo[3,2a]pyrimidin-5-one (3).

group were carried out. By interaction of ketone (3) with semicarbazide, thiosemicarbazide, and 4-methylbenzenesulfonohydrazide the corresponding 2-(1-(3,7-dimethyl5-oxo-5H-thiazolo[3,2-a]pyrimidin-2-yl)ethylidene)hydrazine-1-carboxamide (4a), 2-(1-(3,7-dimethyl-5-oxo-5H-thiazolo[3,2-a]pyrimidin-2-yl)ethylidene)hydrazine-1-carbothioamide (4b), and $\mathrm{N}^{\prime}$-(1-(3,7-dimethyl-5-oxo-5H-thiazolo[3, 2-a]pyrimidin-2-yl)ethylidene)-4-methylbenzene-sulfonohydrazide (4c) were obtained (Scheme 3 ).

In accordance with literature data some heterocyclic substituted oximes and their ethers show fungicidal [47-49], herbicidal [50, 51], insecticidal [52], and growth stimulant [49] activities. Therefore, by reaction of ketone (3) with hydroxylamine hydrochloride, the corresponding 2-(1-(hydroxyimino)ethyl)-3,7-dimethyl-5H-thiazolo[3,2-a]pyrimidin-5-one (4d) was synthesized. The latter with alkyl halides formed 3,7-dimethyl-2-(1-(propoxyimino)ethyl)-5H-thiazolo[3,2-a]pyrimidin-5-one (5a) and 3,7-dimethyl-2-(1-((2phenoxyethoxy)imino)ethyl)-5H-thiazolo[3,2-a]pyrimidin5-one (5b).

We also carried out an electrophilic substitution in the pyrimidine ring to synthesize the halogenated derivatives (6a and $\mathbf{6 b}$ ) of ketone (3) (Scheme 3).

To synthesize the condensed system with a saturated thiazole cycle the reaction of starting 6-methyl-2-thioxo-2,3dihydropyrimidin-4(1H)-one with 1,2-dichloroethane was
(1)

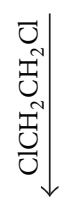

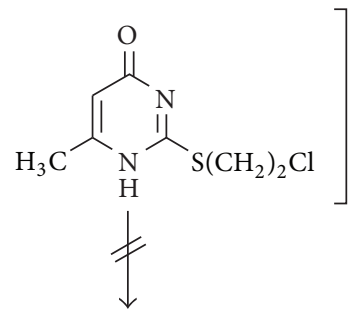<smiles>Cc1cc(=O)n2c(n1)SCC2</smiles><smiles>Cc1cc(=O)nc2n1CCS2</smiles>

(7)

Scheme 4: Synthesis of 7-methyl-2,3-dihydro-5H-thiazolo[3,2a]pyrimidin-5-one.

carried out. As a result 2-((2-chloroethyl)thio)-6-methylpyrimidin-4(3H)-one or 2-((2-chloroethyl) thio)-6-methylpyrimidin-4(1H)-one could be formed (Scheme 4$)$.

In ${ }^{13} \mathrm{C}$ NMR spectrum of the synthesized compound the signal of carbon atom of $\mathrm{C}=\mathrm{O}$ bond is retained, and $\mathrm{C}=\mathrm{S}$ bond has disappeared. In ${ }^{1} \mathrm{H}$ NMR spectrum the values of chemical shift of methylene groups' signals are conformed to Ssubstitution. At the same time, in accordance with elemental analysis and mass spectrum data $(M+1=169)$, there are no chlorine atoms in the molecule of resulting product. Therefore, even at room temperature, the intermediate Ssubstituted derivative is subjected to heterocyclization, and 7methyl-2,3-dihydro-5H-thiazolo[3,2-a]pyrimidin-5-one (7) or 5-methyl-2,3-dihydro-7H-thiazolo[3,2-a]pyrimidin-7-one may be formed. The data of ${ }^{1} \mathrm{H}$ and ${ }^{13} \mathrm{C}$ NMR spectra of the reaction product are similar to those of compound (3), which conform to structure (7). 
2.2. Biological Evaluation. At preliminary screening the herbicidal, fungicidal, and growth regulatory activities of novel synthesized compounds were studied. All preparations did not possess noticeable herbicidal or antifungal properties, but they showed the pronounced growth stimulant activity.

For the growth regulatory properties evaluation the action of aqueous emulsions ( $25 \mathrm{mg} / \mathrm{L}$ and $50 \mathrm{mg} / \mathrm{L}$ ) of synthesized compounds on the germination, growth, and survivability of seeds and seedlings of dicotyledonous bean (Phaseolus vulgaris L.) was studied and compared with that of heteroauxin (IAA).

Two series of bean seeds were incubated for 24 hours in an appropriate medium in the dark at $25^{\circ} \mathrm{C}$. Then the seeds were transplanted into soil and watered daily. The experimental data calculations were produced in 20-25 days. The number of the plants roots of each series, their length and weight in the moist and dry forms, and their average values were calculated. The results were compared with similar data of plants placed in IAA solutions, and the activities of preparations in comparison with IAA (in \%) were determined (Table 1).

Practically all targeted substances (3-6) have shown growth stimulant properties. The most active compounds (more than $70 \%$ compared to heteroauxin) were (3), (4b), (4d), and (6b).

\section{Experimental}

The ${ }^{1} \mathrm{H}$ NMR and ${ }^{13} \mathrm{C}$ NMR spectra were recorded on Varian Mercury- $300 \mathrm{MHz}$ (Varian, USA) spectrometer, in the mixture of solvents DMSO- $d_{6}+\mathrm{CCl}_{4}$ (1:3), using tetramethylsilane as internal standard and IR spectra on Avatar 330FT-IR (Thermo Nicolet, USA) spectrometer, using attenuated total reflectance (ATP) method. Mass spectra were recorded on LC-MS system (Agilent, USA). The X-ray analysis was done at room temperature on automated EnrafNonius CAD-4 diffractometer. The reaction progress and purity of the obtained substances were checked by using TLC method on UV-254 plates ("Silufol," Czech Republic) with acetone/hexane mixture $(2: 1)$ as eluent. All melting points were determined in open capillaries and are uncorrected.

3.1. Synthesis of 6-Methyl-2-thioxo-2,3-dihydropyrimidin$4(1 \mathrm{H})$-one (1). To methanol $(10 \mathrm{~mL})$ was added sodium $(30 \mathrm{mmol})$ and then thiourea $(10 \mathrm{mmol})$ and acetoacetic acid ethyl ester $(10 \mathrm{mmol})$. The mixture was boiled for $7 \mathrm{~h}$, methanol was evaporated, and the precipitate was dissolved in water, neutralized with acetic acid, and filtered off.

Yield (1.26 g, 90\%); light yellow crystals; m.p. $275-277^{\circ} \mathrm{C}$. ${ }^{1} \mathrm{HNMR}: \delta=2.09$ (s, 3H, 6- $\mathrm{CH}_{3}$ ); 5.52 (s, 1H, CH-pyrim.); 11.98 [b.s, $2 \mathrm{H},(\mathrm{NH})_{2}$ ]. ${ }^{13} \mathrm{C}$ NMR: $\delta=17.88 ; 103.38$ 151.91; 160.32; 175.83. Anal. Calcd for $\mathrm{C}_{5} \mathrm{H}_{6} \mathrm{~N}_{2} \mathrm{OS}$ : C, 42.24; $\mathrm{H}, 4.25$; N, 19.70; S, 22.55; found: C, 42.24; H, 4.25; N, 19.70; S, 22.55.

3.2. Synthesis of 3-((4-Hydroxy-6-methylpyrimidin-2yl)thio)pentane-2,4-dione (2). The mixture of 6-methyl-2thioxo-2,3-dihydropyrimidin-4(1H)-one (1) (10 mmol) and $\mathrm{KOH}(10 \mathrm{mmol})$ in dimethylformamide (DMFA) $(15 \mathrm{~mL})$
TABLE 1: Growth stimulant activity of synthesized compounds 3-6.

\begin{tabular}{lc}
\hline Number & Growth stimulant activity compared with IAA (\%) \\
\hline IAA & $100^{\mathrm{a}}$ \\
& $100^{\mathrm{b}}$ \\
$\mathbf{3}$ & $79^{\mathrm{a}}$ \\
& $49^{\mathrm{b}}$ \\
& $64^{\mathrm{a}}$ \\
$\mathbf{4 a}$ & $10^{\mathrm{b}}$ \\
& $75^{\mathrm{a}}$ \\
& $13^{\mathrm{b}}$ \\
$\mathbf{4 b}$ & $39^{\mathrm{a}}$ \\
& $66^{\mathrm{b}}$ \\
4c & $72^{\mathrm{a}}$ \\
& $57^{\mathrm{b}}$ \\
4d & $54^{\mathrm{a}}$ \\
& $66^{\mathrm{b}}$ \\
5a & $55^{\mathrm{a}}$ \\
& $42^{\mathrm{b}}$ \\
5b & $43^{\mathrm{a}}$ \\
& $48^{\mathrm{b}}$ \\
6a & $66^{\mathrm{a}}$ \\
& $74^{\mathrm{b}}$ \\
\hline &
\end{tabular}

${ }^{\mathrm{a}} 50 \mathrm{mg} / \mathrm{L}$.

${ }^{\mathrm{b}} 25 \mathrm{mg} / \mathrm{L}$.

was stirred at room temperature for $3 \mathrm{~h}$; then at cooling 3-chloro-pentane-2,4-dione $(10 \mathrm{mmol})$ was added. The reaction mixture was allowed to stand for $24 \mathrm{~h}$ at $25^{\circ} \mathrm{C}$; then DMFA was evaporated at low pressure and the residue was processed with water and filtered off.

Yield (1.68 g, 70\%); white crystal; m.p. $188-190^{\circ} \mathrm{C}$. ${ }^{1} \mathrm{HNMR}: \delta=2.18$ (s, 3H, 6- $\left.\mathrm{CH}_{3}\right) ; 2.22\left[\mathrm{~s}, 6 \mathrm{H},\left(\mathrm{CH}_{3}\right)_{2}\right] ; 5.92$ (s, $1 \mathrm{H}, \mathrm{CH}$-pyrim.); 12.20 (b.s., $1 \mathrm{H}, \mathrm{OH}$-pyrim.); 17.30 (s, $0.9 \mathrm{H}$, $\mathrm{OH}$-enol). Anal. Calcd for $\mathrm{C}_{10} \mathrm{H}_{12} \mathrm{~N}_{2} \mathrm{O}_{3} \mathrm{~S}: \mathrm{C}, 49.99 ; \mathrm{H}, 5.03 ; \mathrm{N}$, 11.66; S, 13.34; found: C, 49.81; H, 4.91; N, 11.22; S, 13.00 .

3.3. Synthesis of 2-Acetyl-3,7-dimethyl-5H-thiazolo[3,2-a]pyrimidin-5-one (3). A solution of compound 2 (10 mmol) and catalytic amounts of toluene-4-sulfonic acid in toluene $(10 \mathrm{~mL})$ was heated at $125-130^{\circ} \mathrm{C}$ for $4 \mathrm{~h}$. After toluene evaporation water $(20 \mathrm{~mL})$ was added and compound 3 was filtered off from the mixture.

Yield (1.65 g, 75\%); light yellow crystals; m.p. $126-128^{\circ} \mathrm{C}$. IR $(\mathrm{KBr}): v=1695$ and $1705(\mathrm{C}=\mathrm{O}) .{ }^{1} \mathrm{HNMR}: \delta=2.25(\mathrm{~s}$, $\left.3 \mathrm{H}, 7-\mathrm{CH}_{3}\right) ; 2.57$ (s, 3H, $\left.\mathrm{COCH}_{3}\right) ; 3.08\left(\mathrm{~s}, 3 \mathrm{H}, 3-\mathrm{CH}_{3}\right) ; 5.96$ (s, 1H, CH-pyrim.). ${ }^{13} \mathrm{C} \mathrm{NMR:} \delta=16.06 ; 22.85 ; 30.30 ; 105.22$; $120.99 ; 141.69 ; 160.16 ; 160.94 ; 162.60 ; 189.40$. Anal. Calcd for $\mathrm{C}_{10} \mathrm{H}_{10} \mathrm{~N}_{2} \mathrm{O}_{2} \mathrm{~S}$ : C, 54.04; H, 4.54; N, 12.60; S, 14.42; found: C, 53.90; H, 4.39; N, 12.29; S, 14.08.

$X$-Ray Diffraction Analysis. Crystal data: $\mathrm{C}_{10} \mathrm{H}_{10} \mathrm{~N}_{2} \mathrm{O}_{2} \mathrm{~S}$, monoclinic, space group $P 21 / n, a=14.106(3) \AA, b=4.0190(8) \AA$, $c=18.062(4) \AA, \beta=103.32(3)^{\circ}, V=996.4(4) \AA^{3}, Z=4$, 
$T=293(2) \mathrm{K}, d x=1.482 \mathrm{~g} \mathrm{~cm}^{-3}, \mu\left(\mathrm{MoK}_{\alpha}\right)=0.304 \mathrm{~mm}^{-1}$, 3010 data were collected up to $\theta_{\max }=30^{\circ}\left(R_{\text {int }}=0.025\right.$, $\left.R_{\sigma}=0.0678\right)$. Final $R$-indices for 1591 reflections with $I>2 \sigma(I)$ and 139 refined parameters are $R_{1}=0.0562$, $w R_{2}=0.1080\left(R_{1}=0.1283, w R_{2}=0.1328\right.$ for all 2902 data). Crystallographic data for compound (3) have been deposited with the Cambridge Crystallographic Data Centre, deposition number CCDC 991572.

3.4. Synthesis of 2-(1-(3,7-Dimethyl-5-oxo-5H-thiazolo[3,2a]pyrimidin-2-yl)ethylidene)hydrazine-1-carboxamide (4a). The mixture of compound $3(10 \mathrm{mmol})$ and semicarbazide hydrochloride $(10 \mathrm{mmol})$ in water $(10 \mathrm{~mL})$ was heated at $100^{\circ} \mathrm{C}$ for $4 \mathrm{~h}$.

Yield $(2.6 \mathrm{~g}, 89 \%)$; yellow crystals; m.p. $310-312^{\circ} \mathrm{C}$. ${ }^{1}$ HNMR: $\delta=2.25\left(\mathrm{~s}, 3 \mathrm{H}, 7-\mathrm{CH}_{3}\right) ; 2.41\left(\mathrm{~s}, 3 \mathrm{H}, \mathrm{C}=\mathrm{NCH}_{3}\right) ; 2.85$ (s, 3H, 3- $\mathrm{CH}_{3}$ ); 5.92 (s, 1H, CH-pyrim.); 7.25 and 8.20 (b.s, $2 \mathrm{H}$, $\mathrm{NH}_{2}$ ); $10.64(\mathrm{~s}, 1 \mathrm{H}, \mathrm{NH})$. Anal. Calcd for $\mathrm{C}_{11} \mathrm{H}_{13} \mathrm{~N}_{5} \mathrm{O}_{2} \mathrm{~S}: \mathrm{C}$, 47.30; H, 4.69; N, 25.07; S, 11.48; found: C, 47.20; H, 4.55; N, 24.79; S, 11.08.

General Synthesis of Compounds $(\mathbf{4 b}, \boldsymbol{c})$. To a suspension of thiosemicarbazide or toluene-4-sulfohydrazide $(10 \mathrm{mmol})$ in water $(10 \mathrm{~mL}), 36 \% \mathrm{HCl}(12 \mathrm{mmol})$ and compound 3 $(10 \mathrm{mmol})$ were added. The mixture was heated at $100^{\circ} \mathrm{C}$ for $4 \mathrm{~h}$, cooled, and filtered off. The precipitate was purified by boiling in ethanol (50\%).

3.4.1. 2-(1-(3,7-Dimethyl-5-oxo-5H-thiazolo[3,2-a]pyrimidin2-yl)ethylidene)hydrazine-1-carbothioamide (4b). Yield (2.45 g, 84\%); yellow crystals; m.p. $248-2500^{\circ} \mathrm{C} .{ }^{1} \mathrm{HNMR}: \delta$ $=2.24\left(\mathrm{~s}, 3 \mathrm{H}, 7-\mathrm{CH}_{3}\right) ; 2.39\left(\mathrm{~s}, 3 \mathrm{H}, \mathrm{C}=\mathrm{NCH}_{3}\right) ; 2.88(\mathrm{~s}, 3 \mathrm{H}$, 3- $\mathrm{CH}_{3}$ ); 5.90 (s, $1 \mathrm{H}, \mathrm{CH}$-pyrim.); 7.19 and 8.27 (b.s, $2 \mathrm{H}$, $\mathrm{NH}_{2}$ ); 10.55 (s, $\left.1 \mathrm{H}, \mathrm{NH}\right) .{ }^{13} \mathrm{C}$ NMR: $\delta=16.48 ; 17.43 ; 22.85$; $105.06 ; 121.77$; $133.73 ; 140.41 ; 159.96 ; 161.66 ; 161.86 ; 178.99$. Anal. Calcd for $\mathrm{C}_{11} \mathrm{H}_{13} \mathrm{~N}_{5} \mathrm{OS}_{2}$ : C, 44.73; H, 4.44; N, 23.71; S, 21.71; found: C, 44.55; H, 4.29; N, 23.40; S, 21.39 .

3.4.2. $N^{\prime}$-(1-(3,7-Dimethyl-5-oxo-5H-thiazolo[3,2-a]pyrimidin-2-yl)ethylidene)-4-methylbenzenesulfonohydrazide (4c). Yield (3.25 g, 90\%); white crystals; m.p. 208-210 ${ }^{\circ} \mathrm{C} .{ }^{1} \mathrm{HNMR}$ : $\delta=2.21$ and $2.22\left(\mathrm{~s}, 3 \mathrm{H}, 3 \mathrm{H}, \mathrm{CH}_{3}-\mathrm{C}_{6} \mathrm{H}_{5}\right.$ and $\left.7-\mathrm{CH}_{3}\right) ; 2.44(\mathrm{~s}$, $\left.3 \mathrm{H}, \mathrm{C}=\mathrm{NCH}_{3}\right) ; 2.75$ (s, 3H, 3- $\mathrm{CH}_{3}$ ); 5.86 (s, $1 \mathrm{H}, \mathrm{CH}$-pyrim.); 7.32-7.80 (m, 4H, $\left.\mathrm{C}_{6} \mathrm{H}_{4}\right) ; 10.74(\mathrm{~s}, 1 \mathrm{H}, \mathrm{NH}) .{ }^{13} \mathrm{C}$ NMR: $\delta=$ $16.14 ; 17.17 ; 20.94 ; 22.79 ; 104.92 ; 121.34 ; 127.52 ; 128.82 ; 133.48$; $135.88 ; 142.64 ; 145.08 ; 159.95 ; 161.42 ; 161.79$. Anal. Calcd for $\mathrm{C}_{17} \mathrm{H}_{18} \mathrm{~N}_{4} \mathrm{O}_{3} \mathrm{~S}_{2}$ : C, 52.29; $\mathrm{H}, 4.65 ; \mathrm{N}, 14.35 ; \mathrm{S}, 16.42$; found: $\mathrm{C}$, $52.11 ; \mathrm{H}, 4.53 ; \mathrm{N}, 14.02 ; \mathrm{S}, 16.11$.

3.5. Synthesis of 2-(1-(Hydroxyimino)ethyl)-3,7-dimethyl5H-thiazolo[3,2-a]pyrimidin-5-one (4d). To a solution of hydroxyl amine $(11 \mathrm{mmol})$ in water $(10 \mathrm{~mL})$, at cooling a solution of $\mathrm{NaOH}(11 \mathrm{mmol})$ in water $(5 \mathrm{~mL})$ was added dropwise and then compound $3(10 \mathrm{mmol})$ and ethanol $(10 \mathrm{~mL})$. The mixture was allowed to stand for $24 \mathrm{~h}$ and then heated at $50-60^{\circ} \mathrm{C}$ for $2 \mathrm{~h}$, cooled, processed with water, and filtered off.
Yield $(1.65 \mathrm{~g}, 71 \%)$; white crystals; m.p. $214-216^{\circ} \mathrm{C}$. ${ }^{1} \mathrm{HNMR}: \delta=2.23\left(\mathrm{~s}, 6 \mathrm{H}, \mathrm{C}=\mathrm{NCH}_{3}\right.$ and $\left.7-\mathrm{CH}_{3}\right) ; 2.86(\mathrm{~s}, 3 \mathrm{H}, 3-$ $\left.\mathrm{CH}_{3}\right) ; 5.89$ (s, $1 \mathrm{H}, \mathrm{CH}$-pyrim.); 11.66 (s, $\left.1 \mathrm{H}, \mathrm{OH}\right) .{ }^{13} \mathrm{C}$ NMR: $\delta=14.13 ; 16.17 ; 22.77 ; 104.93 ; 119.48 ; 132.27 ; 146.48 ; 159.93$; 161.59; 161.67. Anal. Calcd for $\mathrm{C}_{10} \mathrm{H}_{11} \mathrm{~N}_{3} \mathrm{O}_{2} \mathrm{~S}: \mathrm{C}, 50.62 ; \mathrm{H}, 4.67$; N, 17.71; S, 13.51; found: C, 50.49; H, 4.51; N, 17.39; S, 13.18 .

3.6. General Synthesis of Compounds $(\mathbf{5} \boldsymbol{a}, \boldsymbol{b})$. In DMFA $(20 \mathrm{~mL})$ consecutively $\mathrm{KOH}(10 \mathrm{mmol})$ and compound $4 \mathbf{d}$ $(10 \mathrm{mmol})$ were diluted. The solution was stirred at $20^{\circ} \mathrm{C}$ for $3 \mathrm{~h}$ till salt formation. After cooling propyl bromide or (2-bromoethoxy)benzene (11 mmol) was added. The mixture was allowed to stand for $24 \mathrm{~h}$ and then heated at $70-80^{\circ} \mathrm{C}$ for $2 \mathrm{~h}$. DMFA was evaporated at low pressure; the residue was processed with water and filtered off. Compounds $(\mathbf{5 a}, \mathbf{b})$ were purified by recrystallization from hexane.

3.6.1. 3,7-Dimethyl-2-(1-(propoxyimino)ethyl)-5H-thiazolo[3, 2-a]pyrimidin-5-one (5a). Yield (2.36 g, 85\%); white crystals; m.p. 70-72 ${ }^{\circ} \mathrm{C} .{ }^{1} \mathrm{HNMR}: \delta=0.98$ (t, $J=7.4,3 \mathrm{H}, \mathrm{CH}_{3}-\mathrm{Pr}$ ); $1.72\left(\mathrm{~m}, 2 \mathrm{H}, \mathrm{CH}_{2}\right), 2.24\left(\mathrm{~s}, 6 \mathrm{H}, \mathrm{C}=\mathrm{NCH}_{3}\right.$ and $\left.7-\mathrm{CH}_{3}\right) ; 2.83$ $\left(\mathrm{s}, 3 \mathrm{H}, 3-\mathrm{CH}_{3}\right) ; 4.11\left(\mathrm{t}, J=6.6, \mathrm{OCH}_{2}\right) ; 5.90(\mathrm{~s}, 1 \mathrm{H}, \mathrm{CH}-$ pyrim.). ${ }^{13} \mathrm{C}$ NMR: $\delta=9.85 ; 14.86 ; 16.18 ; 21.77 ; 22.76 ; 75.50$; $104.97 ; 118.02 ; 133.26 ; 147.11 ; 159.82 ; 161.53 ;$ 161.77. Anal. Calcd for $\mathrm{C}_{13} \mathrm{H}_{17} \mathrm{~N}_{3} \mathrm{O}_{2} \mathrm{~S}$ : C, 55.89; $\mathrm{H}, 6.13$; N, 15.04; $\mathrm{S}, 11.48$; found: C, 55.90; H, 6.01; N, 14.69; S, 11.11 .

3.6.2. 3,7-Dimethyl-2-(1-((2-phenoxyethoxy)imino)ethyl)-5Hthiazolo[3,2-a]pyrimidin-5-one (5b). Yield (2.4 g, 67\%); white crystals; m.p. $125-127^{\circ} \mathrm{C}$. IR $(\mathrm{KBr}): v=1679(\mathrm{C}=\mathrm{O})$. ${ }^{1} \mathrm{HNMR}: \delta=2.24$ and $2.26\left(\mathrm{~s}, 3 \mathrm{H}, 3 \mathrm{H}, \mathrm{C}=\mathrm{NCH}_{3}\right.$ and $\left.7-\mathrm{CH}_{3}\right)$; $2.83\left(\mathrm{~s}, 3 \mathrm{H}, 3-\mathrm{CH}_{3}\right) ; 4.23$ and $4.49\left(\mathrm{t}, \mathrm{t}, 4 \mathrm{H}, \mathrm{OCH}_{2} \mathrm{CH}_{2} \mathrm{O}\right)$; 5.91 (s, $1 \mathrm{H}, \mathrm{CH}$-pyrim.); 6.82-7.28 (m, 5H, $\left.\mathrm{C}_{6} \mathrm{H}_{5}\right) .{ }^{13} \mathrm{C}$ NMR: $\delta=15.14 ; 16.23 ; 22.76 ; 65.43 ; 72.54 ; 105.03 ; 114.02 ; 120.18$; $128.76 ; 133.50 ; 148.06 ; 158.01 ; 159.82 ; 1161.55 ; 161.83$. Anal. Calcd for $\mathrm{C}_{18} \mathrm{H}_{19} \mathrm{~N}_{3} \mathrm{O}_{3} \mathrm{~S}$ : C, 60.49; $\mathrm{H}, 5.36 ; \mathrm{N}, 11.76 ; \mathrm{S}, 8.97$; found: C, 60.52; H, 5.22; N, 11.49; S, 8.56.

3.7. General Synthesis of Compounds $(\mathbf{6} \boldsymbol{a}, \boldsymbol{b})$. The mixture of compound $4 \mathbf{d}(10 \mathrm{mmol})$, chlorosuccinimide, or bromosuccinimide $(12 \mathrm{mmol})$ in acetic acid $(20 \mathrm{~mL})$ was heated at $100-110^{\circ} \mathrm{C}$ for $3 \mathrm{~h}$. After acid evaporation the residue was processed with water, neutralized with $\mathrm{NaHCO}_{3}$ till pH 8 and filtered off. Compounds $\mathbf{6 a}, \mathbf{b}$ were purified by recrystallization from hexane-benzene mixture $(1: 1)$.

3.7.1. 2-Acetyl-6-chloro-3,7-dimethyl-5H-thiazolo[3,2-a]pyrimidin-5-one (6a). Yield (2.0 g, 80\%); light brown crystals; m.p. ${ }^{140-142^{\circ} \mathrm{C} .}{ }^{1} \mathrm{HNMR}: \delta=2.43\left(\mathrm{~s}, 3 \mathrm{H}, 7-\mathrm{CH}_{3}\right) ; 2.58$ (s, $\left.3 \mathrm{H}, \mathrm{COCH}_{3}\right) ; 3.10\left(\mathrm{~s}, 3 \mathrm{H}, 3-\mathrm{CH}_{3}\right)$. Anal. Calcd for $\mathrm{C}_{10} \mathrm{H}_{9} \mathrm{ClN}_{2} \mathrm{O}_{2} \mathrm{~S}$ : C, 46.79; $\mathrm{H}, 3.53 ; \mathrm{N}, 10.91 ; \mathrm{S}, 12.49$; found: C, $46.58 ; \mathrm{H}, 3.41 ; \mathrm{N}, 10.57 ; \mathrm{S}, 12.06$.

3.7.2. 2-Acetyl-6-bromo-3,7-dimethyl-5H-thiazolo[3,2-a]pyrimidin-5-one (6b). Yield (2.52 g, 84\%); light brown crystals; m.p. $90-92^{\circ} \mathrm{C} .{ }^{1} \mathrm{HNMR}: \delta=2.48\left(\mathrm{~s}, 3 \mathrm{H}, 7-\mathrm{CH}_{3}\right) ; 2.57$ $\left(\mathrm{s}, 3 \mathrm{H}, \mathrm{COCH}_{3}\right) ; 3.09\left(\mathrm{~s}, 3 \mathrm{H}, 3-\mathrm{CH}_{3}\right)$. Anal. Calcd for 
$\mathrm{C}_{10} \mathrm{H}_{9} \mathrm{BrN}_{2} \mathrm{O}_{2} \mathrm{~S}$ : C, 39.88; H, 3.01; N, 9.30; S, 10.65; found: C, $39.69 ; \mathrm{H}, 2.89$; N, 8.91; S, 10.21 .

3.8. Synthesis of 7-Methyl-2,3-dihydro-5H-thiazolo[3,2-a]pyrimidin-5-one (7). A suspension of compound 3 (10 mmol) and $\mathrm{KOH}(20 \mathrm{mmol})$ in DMFA $(10 \mathrm{~mL})$ was stirred for $3 \mathrm{~h}$ till salt formation; then at cooling $\left(0^{\circ} \mathrm{C}\right)$ 1,2-dichloroethane $(10 \mathrm{mmol})$ was added dropwise and allowed to stand for $24 \mathrm{~h}$ at room temperature. The mixture was filtered off, DMFA was evaporated at low pressure, and the residue was processed with $\mathrm{CHCl}_{3}$ and then with ether.

Yield $(1.2 \mathrm{~g}, 70 \%)$; white crystals; m.p. $118-120^{\circ} \mathrm{C}$. IR $(\mathrm{KBr}): \nu=1660(\mathrm{C}=\mathrm{O}) .{ }^{1} \mathrm{HNMR}: \delta=2.15$ (s, 3H, 7- $\left.\mathrm{CH}_{3}\right)$; $3.49\left(\mathrm{t}, J=7.7,2 \mathrm{H}, \mathrm{SCH}_{2}\right) ; 4.34\left(\mathrm{t}, J=7.7,2 \mathrm{H}, \mathrm{NCH}_{2}\right)$; 5.83 (s, $1 \mathrm{H}, \mathrm{CH}$-pyrim.). ${ }^{13} \mathrm{C} \mathrm{NMR}: \delta=22.76 ; 25.49 ; 48.02$; 106.68; 159.46; 163.22; 163.73. MS: $169(\mathrm{M}+1)$. Anal. Calcd for $\mathrm{C}_{7} \mathrm{H}_{8} \mathrm{~N}_{2}$ OS: C, 49.98; H, 4.79; N, 16.65; S, 19.06; found: C, 49.81; H, 4.65; N, 16.33; S, 18.80 .

\section{Conclusions}

6-Methyl-2-thioxo-2,3-dihydropyrimidin-4(1H)-one (1) can be obtained with high yield $(90 \%)$ on treatment of acetoacetic acid ethyl ester with thiourea in sodium methylate. When the latter reacts with 3-chloro-pentane-2,4-dione, the substitution occurs at sulfur atom (2) and the further regioselective cyclization with good yields afforded 2-acetyl-3,7-dimethyl$5 \mathrm{H}$-thiazolo[3,2-a]pyrimidin-5-one. This three-step synthesis is convenient and efficient and can be used for the syntheses of different biologically active thiazolo[3,2-a]pyrimidine derivatives.

The preliminary biological assay indicates that investigated biheterocyclic system derivatives show growth stimulant activity and can be of interest to obtain new growth regulators.

\section{Competing Interests}

The authors declare no conflict of interests.

\section{References}

[1] B. Tozkoparan, M. Ertan, P. Kelicen, and R. Demirdamar, "Synthesis and anti-inflammatory activities of some thiazolo[3,2a]pyrimidine derivatives," II Farmaco, vol. 54, no. 9, pp. 588$593,1999$.

[2] O. Alam, S. A. Khan, N. Siddiqui, and W. Ahsan, "Synthesis and pharmacological evaluation of newer thiazolo [3,2-a] pyrimidines for anti-inflammatory and antinociceptive activity," Medicinal Chemistry Research, vol. 19, no. 9, pp. 1245-1258, 2010.

[3] H. Zhi, L.-M. Chen, L.-L. Zhang et al., "Design, synthesis, and biological evaluation of $5 \mathrm{H}$-thiazolo[3,2-a] pyrimidine derivatives as a new type of acetylcholinesterase inhibitors," Arkivoc, no. 13, pp. 266-277, 2008.

[4] J. M. Parmar and A. R. Parikh, "Synthesis of thiazolo[3,2a]pyrimidine derivatives as a biologically active heterocycles," Heterocyclic Communications, vol. 4, no. 5, pp. 463-466, 1998.
[5] H. H. Sayed, A. H. Shamroukh, and A. E. Rashad, "Synthesis and biological evaluation of some pyrimidine, pyrimido[2,1b] $[1,3]$ thiazine and thiazolo[3,2-a]pyrimidine derivatives," Acta Pharmaceutica, vol. 56, no. 2, pp. 231-244, 2006.

[6] S. Maddila, G. L. V. Damu, E. O. Oseghe, O. A. Abafe, C. Venakata Rao, and P. Lavanya, "Synthesis and biological studies of novel biphenyl-3,5-dihydro-2H-thiazolopyrimidines derivatives," Journal of the Korean Chemical Society, vol. 56, no. 3, pp. 334-340, 2012.

[7] T. D. Oza, A. Parikh, and V. Gudaparthi, "Synthesis and biological screening of some novel 3-amino-4-arylidene-5-pyrazolones and thiazolo[3,2- $\alpha]$ pyrimidines," Inernational Journal of Pharmaceutical Sciences, vol. 3, no. 4, pp. 2775-2785, 2012.

[8] M. A. Salama and S. A. El-Essa, "Synthesis and reactions of some new 2,3-dihydro-5H-5,7-diarylthiazolo-[3,2-a]pyrimidine-3-one derivatives and their antibacterial and fungicidal activity," Indian Journal of Chemistry Section, vol. 42, no. 1, pp. 173-179, 2003.

[9] M. S. K. Youssef, R. A. Ahmed, M. S. Abbady, S. A. AbdelMohsen, and A. A. Omar, "Reactions of 4-(2-aminothiazole4-yl)-3-methyl-5-oxo-1-phenyl-2-pyrazoline. Synthesis of thiazolo[3,2-a]pyrimidine and imidazo[2,1-b]thiazole derivatives," Monatshefte für Chemie, vol. 139, no. 5, pp. 553-559, 2008.

[10] A.-E.-G. Amr, S. S. Maigali, and M. M. Abdulla, "Microwave assisted synthesis of some new thiazolopyrimidine, thiazolodipyrimidine and thiazolopyrimidine derivatives with potential antioxidant and antimicrobial activity," Monatshefte für Chemie, vol. 139, pp. 1409-1415, 2008.

[11] M. J. Solanki and M. M. Chavda, "Synthesis and antimicrobial activity of some novel derivatives of thiazolo[2,3b]dihydropyrimidine containing 4-pyrazolyl moiety," Rasayan Journal of Chemistry, vol. 4, no. 3, pp. 605-608, 2011.

[12] Q. Chen, X.-L. Zhu, L.-L. Jiang, Z.-M. Liu, and G.-F. Yang, "Synthesis, antifungal activity and CoMFA analysis of novel 1,2,4-triazolo[1,5-a]pyrimidine derivatives," European Journal of Medicinal Chemistry, vol. 43, no. 3, pp. 595-603, 2008.

[13] V. Patel, "Synthesis, characterization and antifungal activity of substituted ethyl 5,7- dimethyl-3-oxo-2,3-dihydro-5H-[1,3]thiazolo[3,2-a]pyrimidie-6-carboxylate derivatives," Der Pharmacia Sinica, vol. 4, no. 5, pp. 72-78, 2013.

[14] M. Bansal, R. Kaur, and B. Kaur, "Synthesis and antifungal evaluation of thiazolo[3,2- $\alpha$ ]pyrimidine," Journal of Applicable Chemistry, vol. 2, no. 3, pp. 391-397, 2013.

[15] S. P. Vartale, D. B. Kadam, N. K. Halikar, and M. M. Pund, "An efficient method for synthesis of novel iminothiazolopyrimidines and plausible antioxidant potential," International Journal of Drug Development and Research, vol. 5, no. 1, pp. 128134, 2013.

[16] E. E. Flefel, M. A. Salama, M. El-Shahat, M. A. El-Hashash, and A. F. El-Farargy, "A novel synthesis of some new pyrimidine and thiazolopyrimidine derivatives for anticancer evaluation," Phosphorus, Sulfur, and Silicon and the Related Elements, vol. 182, no. 8, pp. 1739-1756, 2007.

[17] A. E.-F. G. Hammam, M. A. Sharaf, and N. A. Abd El-Hafez, "Synthesis and anti-cancer activity of pyridine and thiazolopyrimidine derivatives using 1-ethylpiperidone as a synthon," Indian Journal of Chemistry B, vol. 40, no. 3, pp. 213-221, 2001.

[18] M. Said, K. Abouzid, A. Mouneer, A. Ahmedy, and A. M. Osman, "Synthesis and biological evaluation of new thiazolopyrimidines," Archives of Pharmacal Research, vol. 27, no. 5, pp. 471-477, 2004. 
[19] A. M. Mohamed, A.-G. E. Amr, M. A. Alsharari, H. R. M. Al-Qalawi, M. O. Germoush, and R. A. Al-Salahi, "Anticancer activities of some new synthesized thiazolo[3,2-a]pyrido[4,3d]pyrimidine derivatives," American Journal of Biochemistry and Biotechnology, vol. 7, no. 2, pp. 43-54, 2011.

[20] T. P. Selvam, V. Karthick, P. V. Kumar, and M. A. Ali, "Synthesis and structure-activity relationship study of 2 -(substituted benzylidene)-7-(4-fluorophenyl)-5-(furan-2-yl)-2 $\mathrm{H}$ -

thiazolo[3,2-a]pyrimidin-3(7H)-one derivatives as anticancer agents," Drug Discoveries \& Therapeutics, vol. 6, no. 4, pp. 198-204, 2012.

[21] A. Nagaraj and C. Sanjeeva Reddy, "Synthesis and biological study of novel bis-chalcones, bis-thiazines and bis-pyrimidines," Journal of the Iranian Chemical Society, vol. 5, no. 2, pp. 262-267, 2008.

[22] D. B. A. Kumar, G. K. Prakash, M. N. Kumaraswamy, and B. P. Nandeshwarappa, "Microwave assisted facile synthesis of amino pyrimidines bearing benzofuran and investigation of their antimicrobial activity," Indian Journal of Chemistry Section $B$, vol. 45, no. 7, pp. 1699-1703, 2006.

[23] M. B. Buddh, A. H. Bapodra, and K. D. Ladva, "Synthesis and biological evaluation of thiazolo[3,2- $\alpha]$ pyrimidine derivatives as a new type of potential antimicrobial agents," Rasayan Journal of Chemistry, vol. 4, no. 4, pp. 824-828, 2011.

[24] A. E. Rashad, A. H. Shamroukh, R. E. Abdel-Megeid, and W. A. El-Sayed, "Synthesis, reactions, and antimicrobial evaluation of some polycondensed thienopyrimidine derivatives," Synthetic Communications, vol. 40, no. 8, pp. 1149-1160, 2010.

[25] T. I. El-Emary and S. A. Abdel-Mohsen, "Synthesis and antimicrobial activity of some new 1,3-diphenylpyrazoles bearing pyrimidine, pyrimidinethione, thiazolopyrimidine, triazolopyrimidine, thio- and alkylthiotriazolopyrimidinone moieties at the 4-position," Phosphorus, Sulfur and Silicon and the Related Elements, vol. 181, no. 11, pp. 2459-2474, 2006.

[26] M. Bansal, R. Kaur, and B. Kaur, "Synthesis and antimicrobial activities of thiazolo[3, 2-a]pyrimidine derivatives," Asian Journal of Research in Chemistry, vol. 4, no. 1, pp. 116-119, 2011.

[27] H. W. Lee, B. Y. Kim, J. B. Ahn et al., "Molecular design, synthesis, and hypoglycemic and hypolipidemic activities of novel pyrimidine derivatives having thiazolidinedione," European Journal of Medicinal Chemistry, vol. 40, no. 9, pp. 862-874, 2005.

[28] M. Van Laar, E. Volkerts, and M. Verbaten, "Subchronic effects of the GABA-agonist lorazepam and the $5-\mathrm{HT}_{2 \mathrm{~A} / 2 \mathrm{C}}$ antagonist ritanserin on driving performance, slow wave sleep and daytime sleepiness in healthy volunteers," Psychopharmacology, vol. 154, no. 2, pp. 189-197, 2001.

[29] K. S. Nimavat and K. H. Popat, "Synthesis, anticancer, antitubercular and antimicrobial activities of 1-substituted, 3-aryl5-(3'-bromophenyl)pyrazoline," Indian Journal of Heterocyclic Chemistry, vol. 16, p. 333, 2007.

[30] W. J. Houlihan, R. Road, and E. Robert, "Substituted thiazolo[3, 2-a]pyrimidines," US Pat. 3,635,173, 1972.

[31] S. F. Mohamed, E. M. Flefel, A. E.-G. E. Amr, and D. N. Abd ElShafy, "Anti-HSV-1 activity and mechanism of action of some new synthesized substituted pyrimidine, thiopyrimidine and thiazolopyrimidine derivatives," European Journal of Medicinal Chemistry, vol. 45, no. 4, pp. 1494-1501, 2010.

[32] K. Danel, E. B. Pedersen, and C. Nielsen, "Synthesis and antiHIV-1 activity of novel 2,3-dihydro-7H-thiazolo[3,2-a]pyrimidin-7-ones," Journal of Medicinal Chemistry, vol. 41, no. 2, pp. 191-198, 1998.
[33] E. Jeanneau-Nicolle, M. Benoit-Guyod, A. Namil, and G. Leclerc, "New thiazolo[3,2-a]pyrimidine derivatives, synthesis and structure-activity relationships," European Journal of Medicinal Chemistry, vol. 27, no. 2, pp. 115-120, 1992.

[34] A. Balkan, S. Uma, M. Ertan, and W. Wiegrebe, "Thiazolo[3,2a]pyrimidine derivatives as calcium antagonists," Pharmazie, vol. 47, no. 9, pp. 687-688, 1992.

[35] R. Duval, S. Kolb, E. Braud, D. Genest, and C. Garbay, "Rapid discovery of triazolobenzylidene-thiazolopyrimidines (TBTP) as CDC25 phosphatase inhibitors by parallel click chemistry and in situ screening," Journal of Combinatorial Chemistry, vol. 11, no. 6, pp. 947-950, 2009.

[36] S. Kolb, O. Mondésert, M.-L. Goddard et al., "Development of novel thiazolopyrimidines as CDC25B phosphatase inhibitors," ChemMedChem, vol. 4, no. 4, pp. 633-648, 2009.

[37] F. M. Awadallah, "Synthesis, pharmacophore modeling, and biological evaluation of novel $5 \mathrm{H}$-thiazolo[3,2-a]pyrimidin5-one derivatives as $5-\mathrm{HT}_{2 A}$ receptor antagonists," Scientia Pharmaceutica, vol. 76, no. 3, pp. 415-438, 2008.

[38] S. Tetsuo, T. Mikio, H. Hidetoshi, H. Daijiro, and I. Akira, "2Benzylthieno(2,3-d)pyrimidin-4(3H)-one derivative," Japanese Kokai Tokyo Koho JP, 62,132,884, 1987, (Chemical Abstracts, vol. 107, 198350h, 1987).

[39] W. Linder and W. Brandes, "Pesticidal thiazolopyrimidine derivatives," US Pat. 367,820, 1991.

[40] C. J. Shishoo and K. S. Jain, "Synthesis of some novel azido/ tetrazolothienopyrimidines and their reduction to 2,4-diaminothieno[2,3-d]pyrimidines," Journal of Heterocyclic Chemistry, vol. 29, no. 4, pp. 883-893, 1992.

[41] F. Azam, I. A. Alkskas, and M. A. Ahmed, "Synthesis of some urea and thiourea derivatives of 3-phenyl/ethyl-2-thioxo-2,3dihydrothiazolo[4,5-d]pyrimidine and their antagonistic effects on haloperidol-induced catalepsy and oxidative stress in mice," European Journal of Medicinal Chemistry, vol. 44, no. 10, pp. 3889-3897, 2009.

[42] P. K. Chakaravorty, W. J. Grelnlee, K. Dooseap, N. B. Mantlo, and A. A. Patchett, "New pyrimidinone derivatives are angiotensin II antagonists," PCT-The International Patent System WO 92.20.687.156, (Chemical Abstracts 1993, 118, 213104d) 1992.

[43] B. Zhao, L.-L. Jiang, Z. Liu et al., "A microwave assisted synthesis of highly substituted 7-methyl-5H-thiazolo[3,2-a]pyrimidine6-carboxylate derivatives via one-pot reaction of aminothiazole, aldehyde and ethyl acetoacetate," Heterocycles, vol. 87, no. 10, pp. 2093-2102, 2013.

[44] M. Bakherad and F. Gholipoor, "Regioselective syntheses of 3-benzyl-substituted 7H-thiazolo[3,2-a]pyrimidine-7-ones through palladium-catalyzed heteroannulation of acetylenic compounds," Organic Chemistry International, vol. 2012, Article ID 956584, 5 pages, 2012.

[45] M. M. Heravi, A. N. Asar, and M. Bakavoli, "Selective cyclization of 2-propargylthio-6-methyl-pyrimidin-4 $(1 \mathrm{H})$-one to thiazolo[3,2-a]pyrimidin-7-one," Journal of Sciences, Islamic Republic of Iran, vol. 9, no. 1, pp. 27-29, 1998.

[46] N. M. Ahmad and K. Jones, "An efficient synthesis of thiazolo[3,2-a]pyrimidinones," Tetrahedron Letters, vol. 51, no. 25, pp. 3263-3265, 2010.

[47] G. Massolini, M. Kitsos, C. Gandini, and G. Caccialanza, "Fungicidal activity of a series of phenyl pyridyl ketoximes and their O-acetyl derivatives," Pesticide Science, vol. 26, no. 2, pp. 209-214, 1989.

[48] I. H. Aspinall and P. A. Worthington, " $\beta$-Methoxyacrylates; synthesis of new types of strobilurin fungicides with extended 
side chains," Pest Management Science, vol. 55, no. 2, pp. 197-198, 1999.

[49] K. A. Eliazyan, A. M. Knyazyan, V. A. Pivazyan, E. A. Ghazaryan, S. V. Harutyunyan, and A. P. Yengoyan, "Synthesis of 3,4dialkyl-5-(1-oxo-ethyl)-3H-thiazole-2-thiones derivatives and their pesticidal activity," Journal of Heterocyclic Chemistry, vol. 50, no. 5, pp. 1083-1088, 2013.

[50] Suk Jin Koo, S.-C. Ahn, Jae Suk Lim et al., "Biological activity of the new herbicide LGC-40863 benzophenone O-[2,6-bis[(4,6dimethoxy-2-pyramdinyl)oxy]benzoyl]oxime," Pesticide Science, vol. 51, no. 2, pp. 109-114, 1997.

[51] P. J. De Fraine and J. M. Clough, "A new series of broad spectrum of fungicides," Pesticide Science, vol. 44, no. 1, pp. 77-79, 1995.

[52] A. Liu, X. Ou, M. Huang et al., "Synthesis and insecticidal activities of novel oxime ether pyrethroids," Pest Management Science, vol. 61, no. 2, pp. 166-170, 2005. 

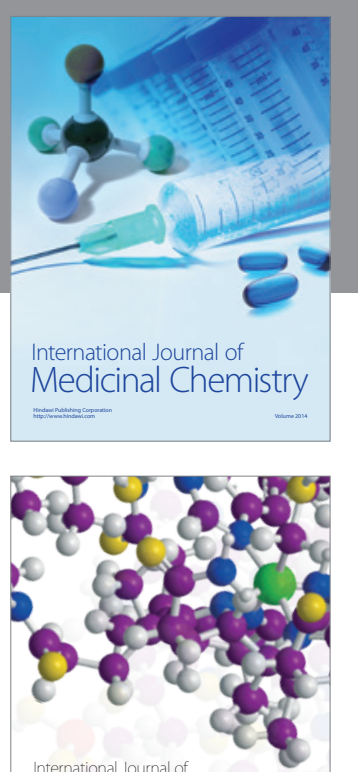

Carbohydrate Chemistry

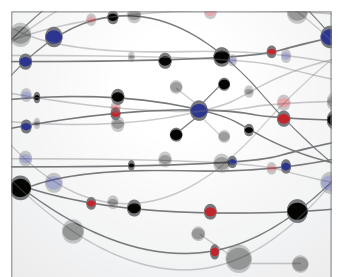

The Scientific World Journal
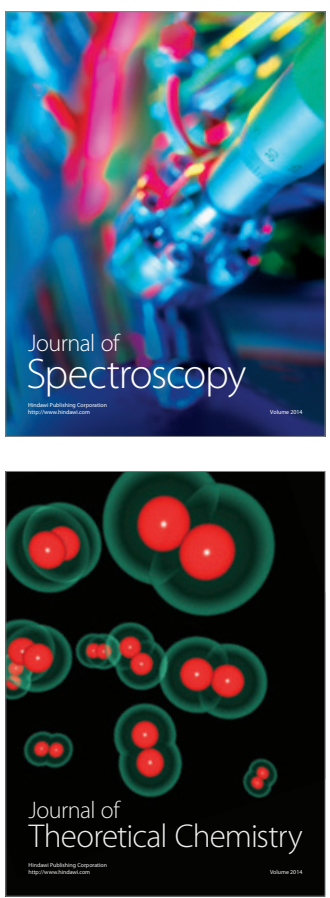
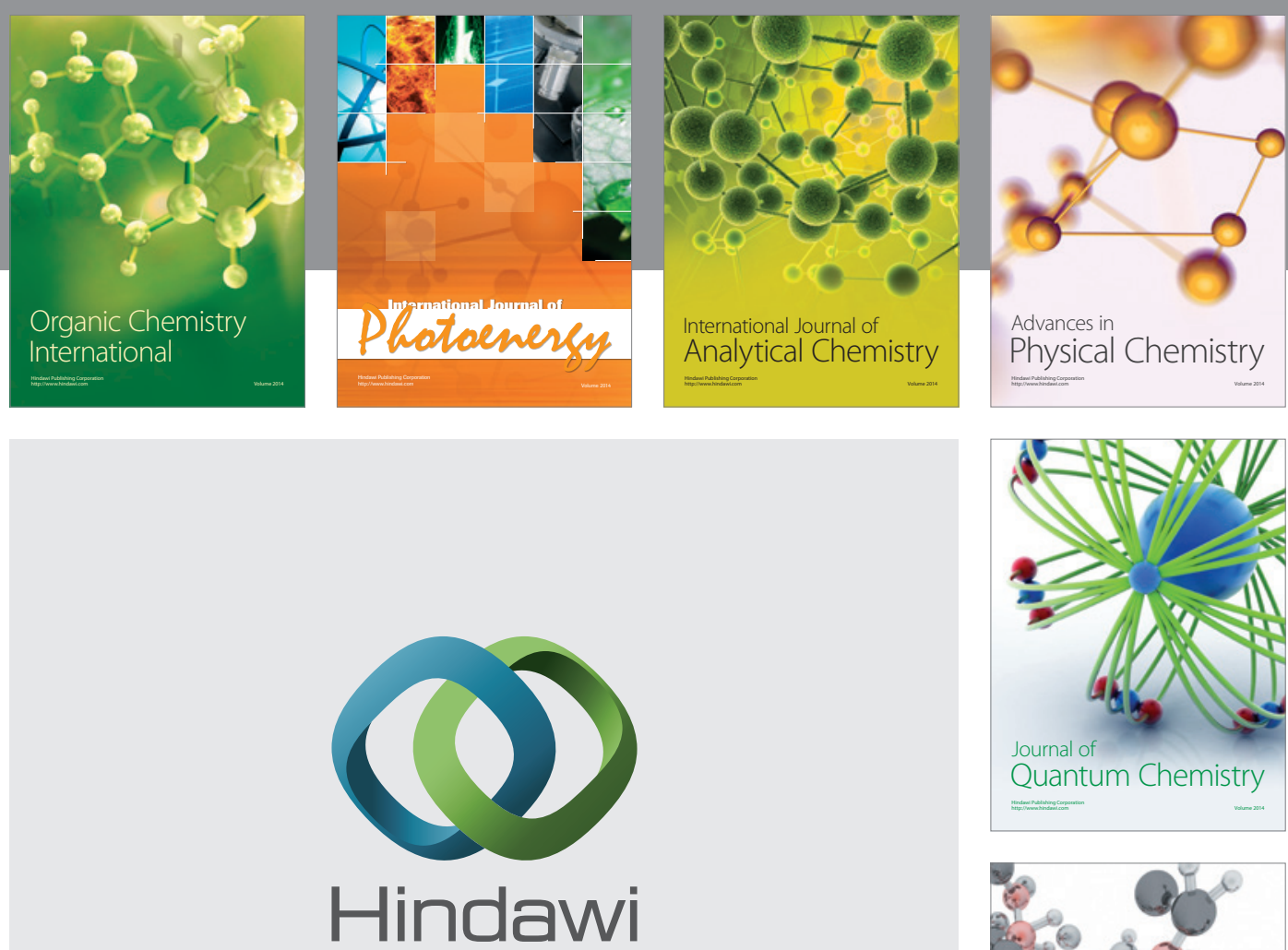

Submit your manuscripts at

https://www.hindawi.com

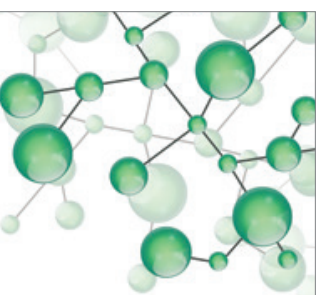

International Journal of

Inorganic Chemistry
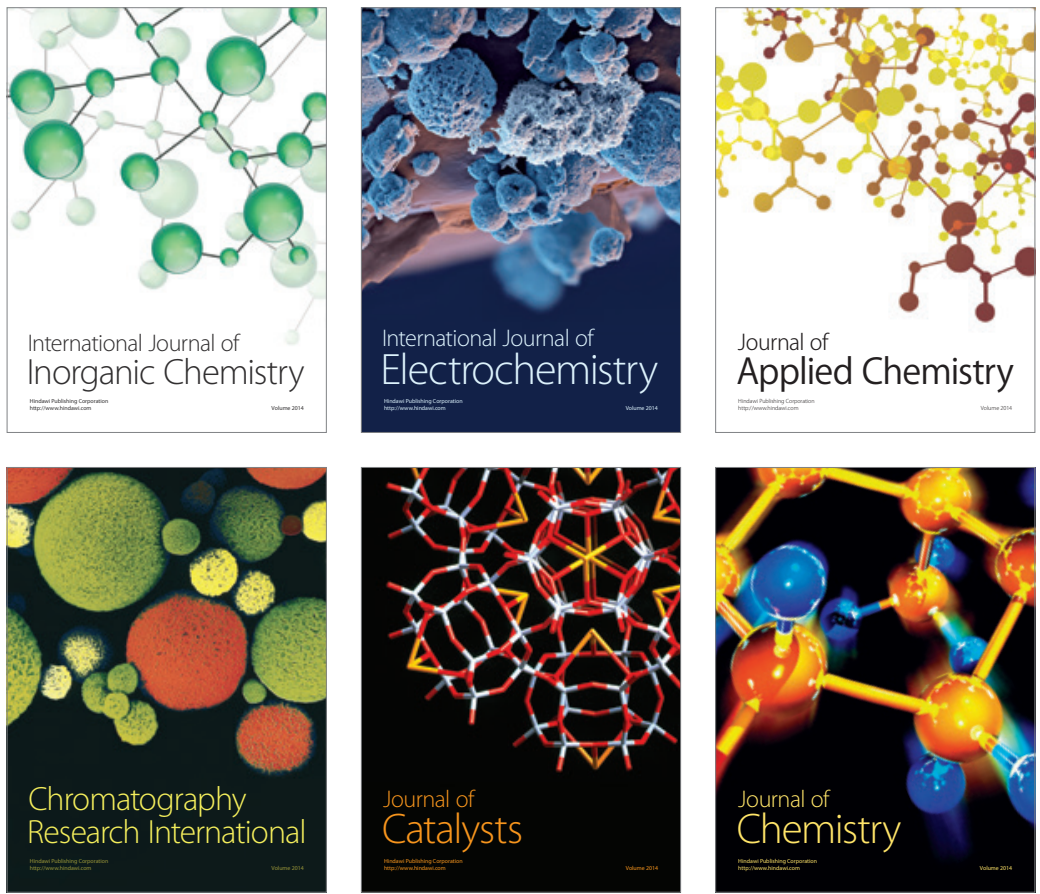

Journal of

Applied Chemistry
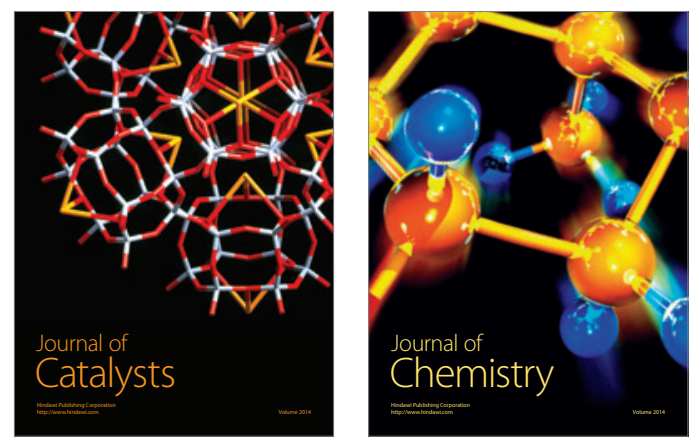
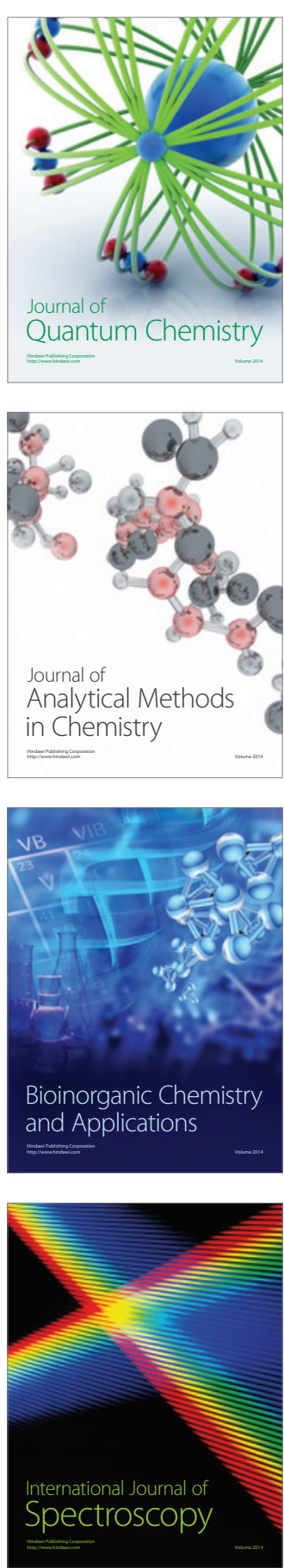